\title{
Blok Aksilar pada Pasien Pseudoaneurisma pada Antebrakii Sinistra yang Disertai Gagal Ginjal Terminal
}

\author{
Yunita Susanto Putri, Dedi Fitri Yadi \\ Departemen Anestesiologi dan Terapi Intensif \\ Fakultas Kedokteran Universitas Padjadjaran/Rumah Sakit Dr. Hasan Sadikin Bandung
}

\begin{abstract}
Abstrak
Pada pasien gagal ginjal terminal yang menjalani hemodialisis dapat terjadi pseudoaneurisma di tempat dilakukannya pintasan arteri vena. Gagal ginjal terminal dapat memengaruhi sistem tubuh yang lain. Hampir semua obat dieksresikan melalui ginjal dan hampir semua obat anestesi menurunkan aliran darah ginjal, glomerular filtration rate, dan produksi urin. Blok aksilar adalah salah satu blok pleksus brakialis yang banyak dilakukan dan dapat menghasilkan blok sempurna untuk prosedur operasi yang dilakukan pada bawah siku tangan. Pada laporan kasus ini, seorang wanita berusia 62 tahun dengan pseudoaneurisma pada pergelangan tangan kiri akibat pintasan arteri vena untuk akses hemodialisis dilakukan evakuasi hematoma dan ligasi arteri radialis sinistra dalam anestesi blok aksilar di Rumah Sakit Dr. Hasan Sadikin Bandung Agustus 2012. Pasien datang dengan kesadaran kompos mentis, tekanan darah 170/80 mmHg, nadi teraba 85 kali per menit kuat regular dengan isi cukup dan saturasi oksigen $96 \%$ dengan udara bebas. Operasi berlangsung selama satu setengah jam dengan keadaan pasien durante operasi tetap stabil. Penanganan anestesi pada pasien dengan gagal ginjal terminal membutuhkan pemahaman perubahan patologis yang berhubungan dengan penyakit ginjal, kondisi medis lain yang menyertai, dan farmakokinetik obat-obatan yang digunakan. Penanganan yang optimal dilakukan untuk meminimalisasi kerusakan ginjal yang telah terjadi sebelumnya.
\end{abstract}

Kata kunci: Blok aksilar, gagal ginjal terminal, pseudoaneurisma

\section{Axillary Block on a Patient with Pseudoaneurism on Left Antebrachii with Terminal Renal Failure}

\begin{abstract}
Patients with end stage renal disease on hemodialysis often developed pseudoaneurysm in the artery venous shunt area. End stage renal disease is a multisystem disease. Most drugs were excreted through the kidney and most anesthesia drugs have the potential in reducing renal blood flow, glomerular filtration rate and urine production. Axilary block is one of the plexus brachialis block commonly used and provide excellent blockade for under elbow procedures. A 62-years-old woman with pseudoaneurysm in the right wrist underwent artery venous shunt procedure for hemodialysis. In this patient, hematoma evacuation was performed and left artery radial was ligated under axilary block anesthesia at Dr. Hasan Sadikin Hospital Bandung August, 2012. Patient was alert with blood pressure $170 / 80 \mathrm{mmHg}$, pulse rate $85 \mathrm{x} /$ minutes and oxygen saturation $96 \%$ on free air. The procedure was performed within about one and half hour, and patient was stable. Anesthesia management in end stage renal disease patient requires an understanding of the pathological changes accompany renal disease, other medical conditions and pharmacokinetics of the used drugs. Optimal management was done to minimalize kidney damage occured previously.
\end{abstract}

Key words: Axilary block, end stage renal disease, pseudoaneurysm

Korespondensi: Yunita Susanto Putri, dr, Departemen Anestesiologi dan Terapi Intensif, Fakultas Kedokteran Universitas Padjadjaran/Rumah Sakit Dr. Hasan Sadikin, Jl. Pasteur No. 38, Bandung, Telp/Faks 022-203 8285/022-203 8056, Mobile 081394505945,Email yunitasputri@yahoo.com 


\section{Pendahuluan}

Gagal ginjal kronik adalah keadaan penurunan fungsi ginjal secara progresif serta permanen yang dapat diakibatkan oleh berbagai macam penyakit. Diabetes melitus merupakan salah satu penyakityang terbanyak sebagai penyebab gagal ginjal terminal, diikuti dengan hipertensi sistemik. Manifestasi klinis gagal ginjal kronik akan bergantung pada tingkat kerusakan ginjal yang digambarkan melalui ketidakmampuan ginjal untuk mengeksresikan sisa nitrogen, melakukan regulasi keseimbangan cairan dan elektrolit, serta sekresi hormon. ${ }^{1}$

Pasien dengan gagal ginjal kronik umumnya membutuhkan pembuatan atau revisi fistula arteriovenula pada anestesi lokal atau regional. Sebelum dilakukan prosedur anestesia, perlu dilakukan evaluasi secara menyeluruh untuk membuktikan bahwa pasien dalam keadaan medis yang telah optimal. Seluruh manifestasi karena uremia harus sudah terkontrol. ${ }^{2}$

Penatalaksanaan anestesia yang diberikan pada pasien gagal ginjal kronik membutuhkan pengertian tentang perubahan patologis yang berhubungan dengan penyakit ginjal, dan juga penilaian apakah penyakit ginjal yang terjadi membutuhkan hemodialisis, obat-obat yang dapat menurunkan fungsi ginjal, perlu dinilai juga apakah penyakit ginjal dalam keadaan stabil ,mengalami perbaikan, atau perburukan. Informasi tersebut dapat diperoleh dengan memantau konsentrasi kreatinin serum. ${ }^{1}$

\section{Laporan kasus}

Seorang wanita berusia 62 tahun dikonsulkan ke Bagian Anestesia Rumah Sakit Dr. Hasan Sadikin Bandung pada Agustus 2012 dengan keluhan benjolan yang semakin membesar, terasa nyeri dan berdarah di dekat pergelangan tangan kiri dengan riwayat operasi pintasan arteri vena untuk akses hemodialisis saat satu bulan sebelumnya, untuk evakuasi hematoma dan juga ligasi arteri radialis sinistra. Pasien tersebut mempunyai riwayat hipertensi yang dikontrol memakai obat amlodipin 1x10 mg per oral serta riwayat diabetes melitus yang dikontrol dengan insulin kerja pendek dengan dosis 6-0-8 unit secara subkutan. Pasien telah menjalani hemodialisis 6 kali yang dilakukan teratur 2 kali seminggu.

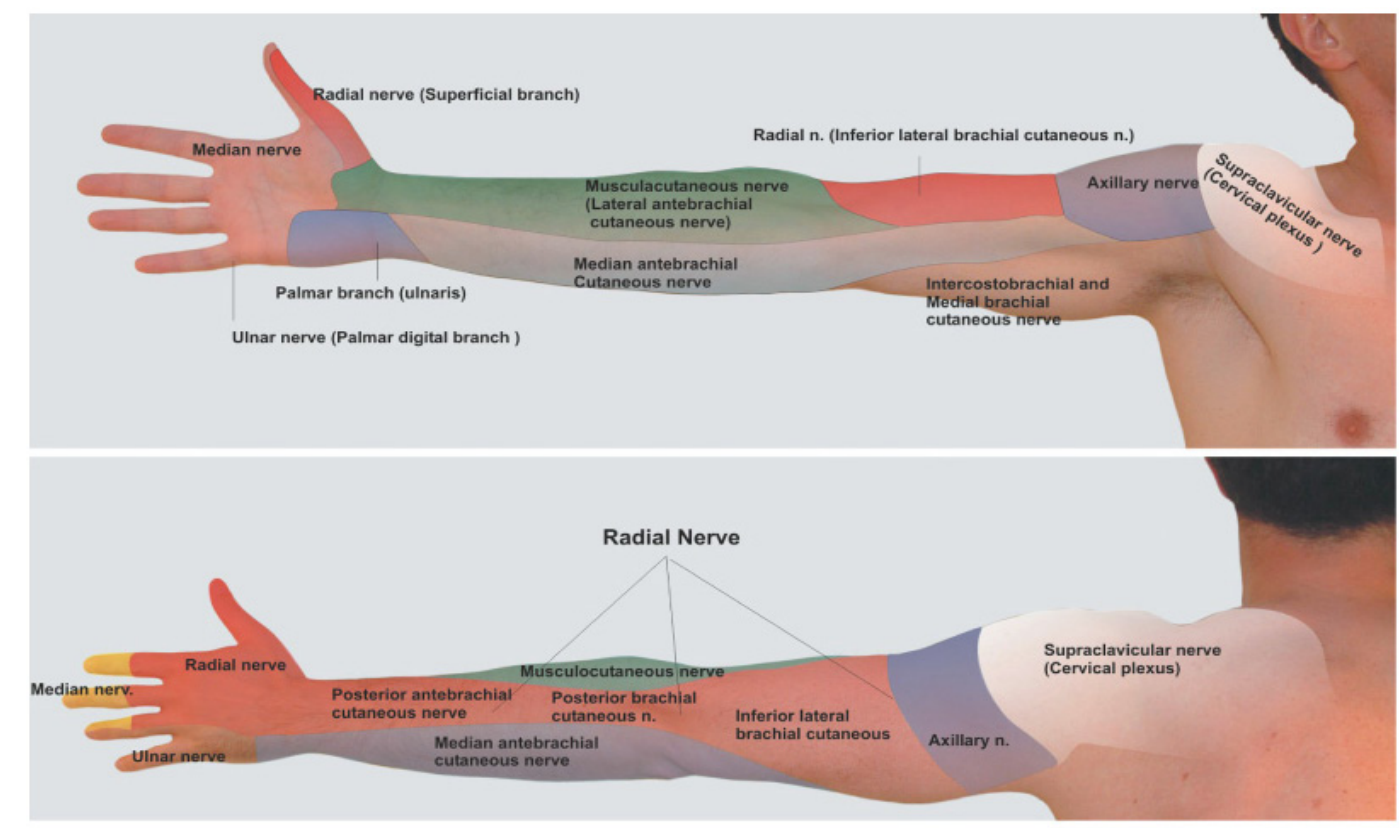

Gambar 1 Distribusi Sensoris Pleksus Brakialis

Sumber: Hadzic. ${ }^{8}$ 
Tabel Obat-obatan Anestesi dan Gagal Ginjal Kronik

\begin{tabular}{lccc}
\hline & $\begin{array}{c}\text { Obat yang Aman } \\
\text { Digunakan }\end{array}$ & $\begin{array}{c}\text { Obat yang Aman dengan Dosis } \\
\text { Lebih Kecil }\end{array}$ & $\begin{array}{c}\text { Obat yang } \\
\text { Kontraindikasi }\end{array}$ \\
\hline Premedikasi & & Lorazepam, midazolam, temazepam & \\
Induksi & Propofol, tiopental, etomidat & Ketamin & \\
Maintenance & Isofluran, desfluran, halotan, & propofol & Sevofluran \\
Pelumpuh otot & Suksinil kolin, sisatrakurium & Vekuronium, rokuronium & Panfluran \\
Opioid & Alfentanil, ramifentanil & Fentanil, morfin & Meperidin \\
Anestesi lokal & & Bupivakain, lidokain & \\
Analgesik & Asetaminofen & & NSAID \\
\hline
\end{tabular}

Sumber: Mcquillan ${ }^{4}$

Saat dikonsulkan untuk operasi emergensi, pasien didapatkan dengan kesadaran kompos mentis, tekanan darah 150/80 mmHg, laju nadi 92x/menit, laju napas 18x/menit, dan saturasi oksigen $97 \%$ dengan udara bebas. Hasil dari pemeriksaan fisis didapatkan sebuah massa hematoma yang berukuran $8 \times 8 \times 5 \mathrm{~cm}$ dengan bruit, sedangkan pada pemeriksaan fisis yang lain dalam batas normal. Hasil pemeriksaan laboratorium pascahemodialisis pada satu hari sebelum operasi didapatkan PT 13 detik, INR 1,09 detik, APTT 31,3 detik, hemoglobin 10,3 $\mathrm{g} / \mathrm{dL}$, hematokrit 31\%, leukosit $17.300 / \mathrm{mm}^{3}$, trombosit $282.000 / \mathrm{mm}^{3}$, gula darah sewaktu $212 \mathrm{~g} / \mathrm{dL}, \mathrm{HbA} 1 \mathrm{C}$ 6,49\%, natrium $132 \mathrm{mEq} / \mathrm{L}$, kalium 3,8 mEq/L, ureum $156 \mathrm{~g} / \mathrm{dL}$, kreatinin $3,4 \mathrm{~g} / \mathrm{dL}$. Hasil rontgen toraks menunjukkan kardiomegali yang tidak disertai bendungan paru. Elektrokardiografi (EKG) menunjukkan irama sinus dengan laju nadi 96x/menit.

Saat pasien tiba di kamar operasi, keadaan umum kompos mentis dengan tekanan darah $170 / 80 \mathrm{mmHg}$, laju nadi $85 \mathrm{x} /$ menit, laju napas $18 \mathrm{x} /$ menit, saturasi oksigen $98 \%$ dengan udara bebas. Blok aksilar dilakukan mempergunakan insulated needle yang berukuran $50 \mathrm{~mm}$ dengan

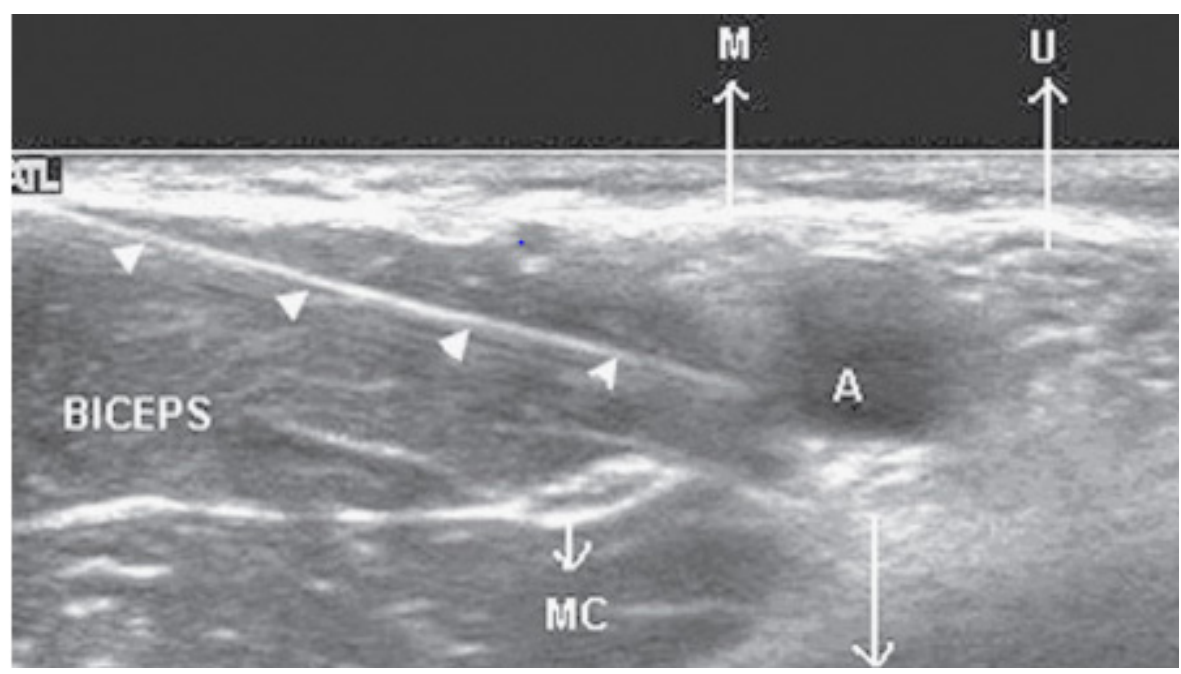

Gambar 2 Gambaran Ultrasonografi Pleksus Brakialis di Daerah Aksilar

Keterangan: A: arteri aksilaris; M: saraf medianus; U: saraf ulnaris; R: saraf radialis; MC: saraf muskulokutaneus

Sumber: Hadzic ${ }^{8}$ 
panduan ultrasonografi dan disuntikkan obat anestesi lokal bupivakain 0,5\% sebanyak $3 \mathrm{~mL}$ di sekeliling masing-masing saraf yang dituju, yaitu saraf radialis, medianus, ulnaris, serta muskulokutaneus sampai terbentuk halo atau biasa disebut doughnut sign.

Sepuluh menit setelah penyuntikan, pasien merasakan hipestesia pada daerah yang akan dilakukan operasi. Sebelum operasi dimulai, dilakukan penilaian ulang fungsi sensoris dan motoris pada masing-masing saraf, kemudian operasi dimulai setelah dipastikan blok saraf berhasil. Operasi berlangsung kurang lebih 1,5 jam. Keadaan pasien saat durante operasi stabil dengan keadaan umum kompos mentis, tekanan darah berkisar antara 160 sampai dengan 175/70-85 mmHg, nadi 80-90 kali per menit, dan saturasi oksigan 97-99\% dengan oksigen 2 liter per menit.

Setelah operasi selesai, pasien dipindahkan ke ruang pemulihan dalam keadaan kesadaran kompos mentis, tekanan darah 160/80 mmHg, laju nadi $80 \mathrm{x} /$ menit, laju napas $18 \mathrm{x} /$ menit, dan saturasi oksigen $99 \%$ dengan oksigen 2 liter/menit melalui selang kanul nasal. Untuk penatalaksanaan nyeri pascaoperasi diberikan parasetamol drip intravena dengan dosis awal $1.000 \mathrm{mg}$, dilanjutkan 3x500 mg intravena selama 24 jam pertama, serta $3 \times 500 \mathrm{mg}$ per oral setelah 24 jam.

\section{Pembahasan}

Gagal ginjal kronik adalah suatu keadaan yang ditandai dengan penurunan fungsi ginjal yang terjadi secara progresif serta permanen pada kurun waktu 3-6 bulan. ${ }^{3}$ Gagal ginjal terminal sering kali diakibatkan oleh diabetes melitus (40\%), hipertensi (27\%), glomerulonefritis kronik (13\%), penyakit polikistikginjal $(3,5 \%)$, nefritis interstitial (4\%), dan penyakit lainnya (12\%). Pada kebanyakan pasien dengan gagal ginjal kronik, penurunan glomerular filtration rate kurang dari $25 \mathrm{~mL} /$ menit ditandai dengan kerusakan progresif pada ginjalyang mengarah pada gagal ginjal terminal yang membutuhkan hemodialisis atau transplantasi ginjal. ${ }^{2-4}$

Pasieninimerupakan pasienyangmenderita gagal ginjal stadium terminal yang disebabkan oleh diabetes melitus serta hipertensi. Pasien gagal ginjal terminal dengan hipertensi dapat dikontrol menggunakan angiotensin converting enzyme (ACE) inhibitor atau juga angiotensin receptor blocker (ARB) dengan target tekanan darah di bawah 130/85 mmHg supaya dapat memperlambat kerusakan ginjal. ${ }^{1-3}$ Kasus ini adalah penderita dengan hipertensi terkontrol dengan amlodipin $1 \times 10 \mathrm{mg}$ per oral, tekanan darah harian 130-150/80-90 mmHg, tetapi pada saat penderita masuk ke dalam kamar operasi, didapatkan tekanan darah 170/80 mmHg yang kemungkinan disebabkan karena pasien merasa cemas.

Pasien juga merupakan penderita diabetes melitus yang terkontrol dengan insulin kerja pendek memakai dosis 6-0-8 unit subkutan. Pada keadaan gagal ginjal terminal dengan hemodialisis, pemberian dosis insulin yang dibutuhkan harus disesuaikan dengan inisiasi hemodialisis. ${ }^{1}$ Pada pasien gagal ginjal sering ditemukan kejadian anemia yang disebabkan oleh gangguan produksi eritropoetin. ${ }^{1}$ Begitu pula pada pasien ini juga ditemukan anemia (hemoglobin 10,3 g/dL).

Pasien dengan hemodialisis disarankan melakukan hemodialisis dalam jangka waktu 24 jam sebelum operasi elektif. Konsentrasi kalium serum sebaiknya tidak lebih dari 5,5 $\mathrm{mEq} / \mathrm{L}$ pada saat hari operasi. ${ }^{1}$ Pasien ini telah menjalani hemodialisis satu hari praoperasi dan didapatkan konsentrasi kalium serum 3,8 $\mathrm{mEq} / \mathrm{L}$.

Untuk pemberian premedikasi disesuaikan keadaan pasien, apabila pasien mempunyai keluhan mual serta muntah atau perdarahan gastrointestinal dapat diberikan $\mathrm{H}_{2}$ blocker. Metoklopramid $10 \mathrm{mg}$ per oral atau intravena dapat diberikan yang bertujuan mempercepat pengosongan lambung, mencegah terjadi mual dan risiko aspirasi. ${ }^{1,2}$ Pada pasien ini diberikan ranitidin $50 \mathrm{mg}$ intravena dan metoklopramid $10 \mathrm{mg}$ intravena kurang lebih satu jam sebelum dilakukan anestesi. Pada pasien gagal ginjal dosis obat yang diberikan harus disesuaikan dengan keamanannya. ${ }^{1}$

Untuk kasus operasi perbaikan aneurisma pada antebrakii sinitra akan lebih dianjurkan dilakukan anestesia blokade pleksus brakialis 
apabila dibandingkan dengan anestesia umum, blokade pleksus brakialis dapat menghasilkan vasodilatasi vaskular sehingga memudahkan ahli bedah dalam melakukan operasi. Sebelum dilakukan blokade, harus diperhatikan dengan pasti bahwa keadaan koagulasi pasien dalam keadaan baik. ${ }^{1}$ Keadaan koagulasi pasien pada kasus ini sebelum dilakukan anestesia blokade pleksus brakialis dalam batas normal.

Teknik blokade pleksus brakialis terdiri atas teknik blokade interskalenus, supraklavikular, infraklavikular, dan juga aksilar. ${ }^{5}$ Pada kasus ini, dipilih blokade aksilar dengan pertimbangan daerah operasi yang dilakukan berada pada daerah volar lengan bawah, dan blok aksilar merupakan teknik blokade saraf perifer yang memang diindikasikan pada operasi di daerah tangan, lengan bawah, dan siku. Selain itu, blok aksilar juga mudah untuk dilakukan dan efek samping minimal dibandingkan dengan blok pleksus brakialis lainnya. Blok aksilar meliputi 4 (empat) saraf, yaitu saraf ulnaris, medianus, radialis, dan muskulokutaneus. ${ }^{6,7}$

Ada beberapa teknik untuk melakukan blok aksilar, yaitu teknik tanpa bantuan alat, dan dengan bantuan stimulasi saraf, serta bantuan ultrasonografi. ${ }^{8}$ Kesuksesan blokade aksilar adalah dengan memahami orientasi terhadap 4 (empat) nervus terminal yang mengelilingi arteri aksilaris, yaitu nervus ulnaris, medianus, radialis, dan juga muskulokutaneus. ${ }^{6}$ Pasien diposisikan supinasi dengan lengan abduksi 70-80 derajat dan juga dalam keadaan rotasi eksternal, siku fleksi 90 derajat, dan dorsum manus menghadap ke arah meja operasi. Cara melakukan blok ini dapat dilakukan dengan teknik nerve stimulation atau dengan memakai bantuan ultrasonografi. ${ }^{8}$

Dahulu, blokade aksilar dilakukan tanpa alat bantu dengan mengandalkan anatomi sebagai acuannya. Arteri aksilaris diraba dan anestetik lokal disuntikkan di sekeliling arteri dengan memasukkan anestetik lokal dalam volume yang banyak (30-40 $\mathrm{mL}$ ) sehingga diharapkan dapat menggenangi seluruh nervus. Namun angka keberhasilan blokade memakai teknik ini sangat rendah, terutama untuk blok nervus muskulokutaneus dikarenakan letak nervus ini jauh dari arteri aksilaris, sehingga meskipun dengan penambahan volume anestetik lokal tetap saja sulit memblok nervus ini. ${ }^{8,9}$

Pada saat ini teknik blokade aksilar sering dilakukan dengan panduan alat stimulasi saraf menggunakan jarum insulated needle, dengan panduan alat ini blok yang dihasilkan menjadi lebih baik dibandingkan dengan teknik tanpa alat bantu. Meskipun memakai bantuan alat, blok ini masih mungkin mengalami kegagalan karena penyebaran anestetik lokal yang tidak dapat dilihat secara langsung. ${ }^{8-10}$

Teknik blokade saraf tepi terbaru adalah menggunakan bantuan ultrasonografi, dengan memakai teknik ini, maka angka keberhasilan blokade menjadi lebih tinggi karena saraf yang dituju dan juga penyebaran obat anestesi lokal dapat dilihat langsung, yaitu gambaran hitam mengelilingi area nervus yang berwarna putih (doughnut sign). ${ }^{8}$ Pada pasien ini, digunakan teknik blokade menggunakan ultrasonografi. Pemilihan teknikini karena angka keberhasilan yang lebih tinggi dan juga mengurangi volume anestetik lokal yang diberikan.

Pemberian anestetik lokal dengan bantuan ultrasonografi diberikan secara bertahap 2-3 $\mathrm{mL}$ pada setiap saraf sampai terbentuk halo di sekitar saraf. ${ }^{11}$ Pada pasien ini anestetik lokal yang digunakan adalah $3 \mathrm{~mL}$ bupivakain 0,5\% pada setiap saraf, sehingga total bupivakain yang diberikan adalah $12 \mathrm{~mL}$. Blok tercapai sempurna dalam waktu 10 menit dengan durasi selama 6 jam. Selama operasi berlangsung dan pascaoperasi keadan pasien tetap stabil, tidak ada perubahan hemodinamik yang bermakna.

\section{Simpulan}

Teknik blokade aksilar dapat dijadikan sebagai pilihan dibandingkan dengan anestesia umum pada kasus operatif di daerah lengan bawah yang disertai gangguan fungsi organ, seperti gagal ginjal terminal. Pemilihan teknik blokade aksilar pada kasus-kasusyang disertai penyakit kritis dapat meminimalkan pemberian obatobatan yang berefek memperberat penyakit pasien akibat efek obat-obat anestesi terhadap fisiologi atau organ yang terganggu, sehingga diharapkan memberikan hasil yang lebih baik dengan komplikasi minimal. 


\section{Daftar Pustaka}

1. Garwood S. Renal disease. Dalam: Hines RL, Marschall KE, penyunting. Stoelting's anesthesia and co-existing disease. Edisi ke-5. Amerika Serikat: Churchill Livingstone; 2008. hlm. 329-40.

2. Morgan GE, Mikhail MS, Murray MJ, penyunting. Clinical anesthesiology. Edisi ke-4. Amerika Serikat: McGraw-Hill Companies; 2006.

3. Dhar P, Yao FS. Kidney transplant. Dalam: Yao FS, penyunting. Yao \& Artusio's anesthesiology: problem oriented patient management. Edisi ke-6. Amerika Serikat: Lippincott Williams \& Wilkins; 2008. hlm. 822-47.

4. McQuillan PM. Oxford American handbook of anesthesiology. Edisi ke-1. New York: Oxford University Press Inc.; 2008.

5. Rathmell JP, Neal JM, Viscomi CM. Regional anesthesia: the requisites in anesthesiology. Edisi ke-1. Philadelphia:
Mosby; 2004.

6. Tsui BCH, Rosenquist RW. Peripheral nerve blocked. Dalam: Barash PG, Cullen BF, Stoelting RK, penyunting. Clinical anesthesia. Edisi ke-6. Philladelphia: Lippincott Williams \& Wilkins; 2009. hlm. 976-7.

7. European Society of Regional Anaesthesia \& Pain Therapy (ESRA). Handbook regional anestesia. European Society of Regional Anaesthesia \& Pain Therapy (ESRA); 2007.

8. Hadzic A. Peripheral nerve blocks and anatomy for ultrasound guided regional anesthesia. Edisi ke-2. New York: New York School of Anesthesia; 2006.

9. Chan VW. Ultrasound imaging for regional anesthesia a practical guide. Edisi ke-2. Amerika Serikat: Springer; 2010.

10. Brown DL. Atlas of regional anesthesia. Edisi ke-4. Amerika Serikat: Elsevier; 2010.

11. Chelly JE. Peripheral nerve blocks: a color atlas. Edisi ke-3. Amerika Serikat: Lipincott Williams \& Wilkins; 2009. 